\title{
A literature review on burning mouth syndrome
}

\author{
Sung-Hyeon Choi', Bin-Na Lee, Hae-Soon Lim², Won-Mann Oh¹, Jae-Hyung Kim³ \\ 'Department of Conservative Dentistry, School of Dentistry, Chonnam National University, Gwangju, Republic of Korea \\ ${ }^{2}$ Department of Dentistry Education, School of Dentistry, Chonnam National University, Gwangju, Republic of Korea \\ ${ }^{3}$ Department of Oral Medicine, School of Dentistry, Chonnam National University, Gwangju, Republic of Korea
}

Burning mouth syndrome (BMS) is defined as the xerostomia, burning sensation and various discomfort of tongue and oral mucosa. BMS can occur in both men and women, but is more frequent in middle-aged menopausal women. Because exact cause can't be identified clearly and it is hard to make diagnosis in clinic, the purpose of the treatment have been to relieve symptoms. Etiology of BMS is divided into local, systemic, and psychological factors. $\alpha$-lipoic acid, clonazepam, supplemental therapy and cognitive behavior therapy can be prescribed for BMS. Nowdays, many experts focus attention on effect of combination therapy. It is necessary to solve the symptoms of the patients by combination of pharmacological approach and psychotherapy with cognitive behavior therapy considering the factors in various aspects. (J Dent Rehabil Appl Sci 2019;35(3):123-31)

Key words: burning mouth syndrome; clinical features; etiology; diagnosis; treatment

\begin{abstract}
서론
남성보다는 여성에서, 특히 폐경기 이후 중년 여성에 게서 훨씬 더 빈발하고 있는 구강작열감 증후군(Burning mouth syndrome; BMS)은 입 안에 어떤 임상적인 구강 점막의 변화와 비정상적인 소견 없이 타는 듯한 느낌(작 열감)을 호소한다. 대부분 혀끝과 혀 바깥측면의 작열감 을 가장 많이 호소하고 입술과 경구개, 연구개에서의 작 열감, 그 밖에 미각의 변화, 구강건조감 등의 불편함을 호 소하는 증후군이다. ${ }^{1} \mathrm{BMS}$ 라는 용어는 타는 듯하거나 찌 르는 듯한 느낌, 가려움 등의 피부감각이상을 주로 호 소하는 환자들의 상태를 나타내기 위해 Koo와 Gambla 에 의해 처음 사용되었다. ${ }^{2}$ 최근에는 점막이상 같은 뚜렷 한 임상 소견이 없는 상태에서 혀 및 기타 구강점막의 작 열감을 일컫었고, 유사한 증상을 나타내어도 고유의 분 명한 원인이 있는 증상은 제외시켰다. 국제두통협회는
\end{abstract}

*Correspondence to: Jae-Hyung Kim

Professor, Department of Oral Medicine, School of Dentistry, Chonnam National University, Youngbong-ro 77, Buk-gu, Gwangju, 61186, Republic of Korea

Tel: +82-62-530-5678, Fax: +82-62-530-5679, E-mail: tmjkim@jnu.ac.kr

Received: July 1, 2019/Last Revision: July 30, 2019/Accepted: August 9, 2019
$\mathrm{BMS}$ 를 어떤 의학적 또는 치과적 원인이 없는 구내 작열 감으로 정의하였다. ${ }^{3} \mathrm{BMS}$ 에 대한 연구는 최근 많이 진행 되고 있지만 그 원인은 아직 명확하게 밝혀지지 않았다. 그리하여 환자들도 $\mathrm{BMS}$ 라는 진단을 받기까지의 치료과 정에 있어 시행착오를 겪게 되면서 의료진에 대한 신뢰감 이 떨어지고 임상적으로 통증과 구강 내 불편감이 심해 졌다. 뿐만 아니라 심리적으로도 불안감이 커지며 자신 이 암에 걸린 것은 아닌가 하는 공포감을 가지는 경우도 생겼다. 본 문헌고찰에서는 $\mathrm{BMS}$ 에 대한 임상적 특징, 병 인 및 치료법에 대해 정리해보고자 한다.

\section{문헌고찰}

$\mathrm{BMS}$ 는 연구자들에 따라 여러 타입으로 분류되어 왔 는데 그 중에서도 Muzyka와 Rossi ${ }^{4}$ 분류법이 주로 이용 되고 있고, Scala 등 ${ }^{5}$ 의 분류법 또한 자주 이용되고 있다

Copyright C 2019 The Korean Academy of Stomatognathic Function and Occlusion. (c) It is identical to Creative Commons Non-Commercial License. 
Table 1. Classification of burning mouth syndrome (BMS)

\begin{tabular}{ll}
\hline Authors & \multicolumn{1}{c}{ Characteristics by subtype } \\
\hline Muzyka and De Rossi ${ }^{4}$ & - Type 1 \\
& - Burning sensation is not present upon waking, but which develops and progresses during \\
& the waking hours, with the greatest intensity of discomfort in the evening \\
& - Approximately 35\% of BMS patients \\
& - Foods or drink alleviate symptoms \\
& - Type 2 \\
& - Awake with a burning sensation that is constant throughout the waking period \\
& - Present daily \\
& - Approximately 55\% of BMS patients \\
& - Foods or drink alleviate symptoms \\
& - Type 3 \\
& - Symptoms on occasion, increased incidence of contact allergies \\
& - Unusual intra-oral sites affected such as mouth floor and buccal mucosa \\
& - Foods or drink aggravates symptoms \\
& - Primary or idiopathic BMS \\
- Condition in which cause of BMS is not clearly identified. & - Secondary BMS \\
- As a result of local and/or systemic factors
\end{tabular}

(Table 1). 본 논문에서도 Muzyka와 Rossi 분류법을 사 용하였다.

\section{역학(Epidemiology)}

연구자들마다 약간의 차이가 있지만 Locker 등 ${ }^{6}$ 이 보 고한 BMS 발병률은 $2.5-5.1 \%$, Klasser 등 은 $0.7-5 \%$, Bergdahl 등 ${ }^{8}$ 은 3.7 - 18\%, Jaaskelainen ${ }^{9}$ 은 $40 \%$ 까지 발 병했다고 보고하였다. Lamey와 $\mathrm{Lamb}^{10}$ 은 폐경기 치료센 터 환자들의 $10-20 \%$ 에서 입과 혀의 작열감이 발병했다 고 보고하였다.

50 대에서 70 대 사이의 여성에서 주로 발병하였는데 ${ }^{1}$ 특히 55세 이상의 폐경기 이후 여성에서 발병률이 높아졌 고(23.1\%), 20 - 39세 연령대에서의 발병률 $(0.6 \%)$ 이 가장 낮았다. ${ }^{8}$ 구강악안면 통증을 호소하는 55 세 이상의 한국 환자들을 대상으로 한 연구에서도 13.6 - 15.2\%의 발병 률을 보고하였고, ${ }^{11}$ 이러한 수치는 다른 연구들에서의 발 병률과 비슷하였다.

여성과 남성에서 약 7:1 - 13:1 정도로 여성에서의 발병 률이 훨씬 높다는 것을 알 수 있다. ${ }^{12}$ Grushka ${ }^{1}$, Bergdahl 과 $\mathrm{Bergdahl}^{8}$ 의 연구에 따르면 폐경 3년 전부터 폐경 후 12 년 사이에 발병률이 특히 더 높아졌고, 이로써 BMS가 폐경과 관련 있다고 여겨진다.

\section{임상적 특징 (Clinical features)}

$\mathrm{BMS}$ 는 증상의 개시나 강도가 일정하지 않았다. 대부 분의 $\mathrm{BMS}$ 환자들은 구강작열감을 느꼈고, 혀 전방 $2 / 3$, 특히 혀 끝(tip)과 양측면, 입술과 볼, 그리고 경구개 점 막에서의 통증을 호소하기도 하였다. ${ }^{13}$ 뿐만 아니라 협점 막, 구인두, 구강저에서의 작열감도 보고되었다. ${ }^{1}$ 이런 증 상은 환자들의 $50 \%$ 이상에서 자발적으로 시작되었고, 촉 발시키는 요소는 없었다. 환자들 중 $1 / 3$ 은 치과치료과정, 최근 질환, 약물, 스트레스와 관련 있었고 일단 증상이 시 작되면 통증이 수년 동안 지속되었다. ${ }^{13}$

또한 대부분의 BMS 환자들은 실제로 타액의 양이나 흐름의 감소가 일어나지 않는데도 입이 마른다는 주관적 인 감각을 호소하였다. ${ }^{13}$ 한 연구결과에 따르면 $\mathrm{BMS}$ 환 자들에서 타액선 기능저하를 동반하지 않고 구강건조감 을 느끼는 경우가 $46-67 \%$ 에 달한다고 하였다. ${ }^{8}$

미각장애 역시 $\mathrm{BMS}$ 환자들의 $70 \%$ 정도에서 호소할 만큼 매우 보편적인 증상이었다. ${ }^{8}$ 어떤 환자들은 음식 향 의 강도를 인지하는데 있어 변화를 느끼는 반면에 또 어 떤 환자들은 짜거나, 쓰거나, 시거나 금속 맛과 같은 입 안에서 이상한 맛이 지속되는 형태의 증상을 호소하는 경우가 있고 보통 구강건조감과 동반되었다. ${ }^{14}$ 미각장애 는 갑상선기능저하증과 관련될 가능성 있기 때문에 혈액 
검사를 통해 전신질환을 배제시켜야 한다. ${ }^{15}$

$\mathrm{BMS}$ 환자의 $20 \%$ 정도에서는 명확한 원인 없이 겪게 되는 불편감으로 인해 암에 대한 공포감을 느끼고 있었 다. ${ }^{16}$

\section{병인(Etiology)}

BMS의 병인에 대해서는 합의된 의견이 없지만 대체로 국소적, 전신적 및 정신적 요인들과 연관이 있었다.

국소적 요인으로서 의치 디자인 오류나 의치상 재료에 의한 염증에 의해 BMS가 발병되기도 하였다. Basker 등 ${ }^{17}$ 은 그들의 환자 $50 \%$ 에서 의치 디자인 오류 때문이라고 보고하였는데 가장 보편적인 디자인 오류는 교합, 특히 자유로 간극(freeway space)이 없거나 균형적이지 못한 교합이 원인이었다. 또한 매끄럽지 못한 의치 표면, 혀 공 간의 제한 등도 원인 요소로 여겨졌다.

지속적으로 타는 듯한 통증과, 접촉되는 점막에 미만 성의 홍반은 의치상 재료에 의한 알러지와 관련 있었던 반면, 점막은 정상이면서 구강 전체에 간헐적으로 느껴지 는 작열감은 식품에 의한 알러지와 관련 있었다. 음식, 보 존제, 첨가제, 향미료 등에 대한 알러지는 type $3 \mathrm{BMS}$ 의 $65 \%$ 에서 주된 원인이었다. ${ }^{18}$

여러 전신적 요인들 중 먼저 여성호르몬 변화를 들 수 있다. 폐경기 이후의 중년 여성에서 BMS가 급격하게 증 가하였던 것으로 보아, 여성의 폐경과 BMS가 밀접한 관 련이 있는 것으로 여겨진다. 폐경기 치료 클리닉의 114 명 을 대상으로 한 연구에서 참가자 중 $26 \%$ 가 구강 내 불편 증상을 가지고 있었는데, 그 중 $43 \%$ 는 단지 작열감만, $27 \%$ 는 미각이상, $30 \%$ 는 작열감과 미각이상 두 가지 모 두 호소하였다. ${ }^{17}$ Wardrop 등 ${ }^{19}$ 의 보고에 따르면, 폐경 이 전 여성들에서는 단지 $6 \%$ 에서만 구강 내 불편감을 호소 한 것에 비해, 폐경기 즈음이나 폐경 이후 여성들에서는 $43 \%$ 에서 구강 내 불편감을 호소하였다. Gao 등 ${ }^{20}$ 은 정 상대조군에 비해 $\mathrm{BMS}$ 를 지닌 폐경기 혹은 폐경 이후 여 성환자들 그룹에서 혈청 여포자극호르몬 수치가 유의하 게 더 높았고, 혈청 여성호르몬(estradiol) 수치가 유의하 게 낮았음을 보고하였다.

Woda 등 ${ }^{21}$ 은 생식선, 부신, 신경자극성 스테로이드 수 치와 BMS와의 관련성을 보고하였고, Zakrzewska른 신 경자극성 스테로이드 생성에 변화를 일으키는 생식선 스 테로이드의 급격한 감소를 언급하면서 폐경과의 관계를 제안하였다.
영양결핍에 의해서도 $\mathrm{BMS}$ 증상이 야기되었다. 비타민 $\mathrm{B}$ 복합체, 철, 아연 등이 결핍되었을 때 주로 혀의 끝 부위 에서 작열감이 느껴졌다고 발표했고, ${ }^{9}$ 다른 연구에서도 $\mathrm{BMS}$ 환자들에서 헤모글로빈, 철, 비타민 B12 결핍 정도 가 유의하게 더 높았다. ${ }^{23}$ Lamey 등 ${ }^{24}$ 은 비타민 $\mathrm{B}_{1,2,6}$ 의 대 체 요법이 영양결핍환자들의 $88 \%$ 에서 구강작열감 감소 에 유익했다고 보고하였다.

끝으로 자가면역질환들 중 섬유근육통 환자의 $32.8 \%$ 에서 BMS가 나타났는데 이들의 가장 흔한 구강 내 증 상으로는 구강건조감 $(70.9 \%)$, 악안면관절 기능이상 (67.6\%), 실어증 $(37.3 \%)$, 미각상실 $(34.2 \%)$, 구강통증 $(32.8 \%)$ 등 이었다. ${ }^{25}$

또한 불안, 우울증, 강박장애, 정신사회적 스트레스, 암 공포증 등과 같은 심리적 요소도 BMS와 관련이 있었다. $\mathrm{BMS}$ 환자들의 $62 \%$ 에서 불안장애와 우울증을 동반하 였고, ${ }^{26}$ 불안장애가 더 심해지면 암공포증으로 악화되었 다. BMS 환자들의 $20-30 \%$ 는 암이 아닐까 하는 불안감 을 가지고 있었고, ${ }^{27}$ Lamey 등 $^{28}$ 도 정상대조군에서보다 $\mathrm{BMS}$ 환자들에서 2.7배 더 암공포증을 느낀다고 보고하 였다. Amenabar 등 ${ }^{29}$ 역시 정상인에서보다 BMS 환자들 에서 불안장애점수와 타액 내의 코티솔 농도가 높다는 것을 보였다. 이는 스트레스를 받을 때 인체 내에서 코티 솔 분비가 증가한다는 점을 미루어볼 때, 정신적인 스트 레스가 BMS 발병에 영향을 미친다고 여겨진다.

\section{진단(Diagnosis)}

BMS의 진단은 일단 환자의 현재 존재하는 증상들에 의존하고, 구강작열감을 일으킬 수 있는 다른 잠재적인 요인들을 모두 제거한 후에 얻을 수 있기 때문에 매우 복 잡하므로 환자들이 겪는 증상 유형에 대해 주의 깊은 분 석이 필요하다. 그러므로 오랜 기간 구강작열감을 느껴 온 환자가 내원했을 때 의과적 및 치과적 병력을 세세히 파악해야 하고, 구강점막을 검사하여 이상이 없음에도 불구하고 구강작열감을 호소하는 경우 $\mathrm{BMS}$ 로 진단할 수 있다. 만약 구강점막에 이상이 있는 경우 혈액검사, 미 생물검사 또는 조직검사를 시행하여 최종진단을 내린 후 그에 따른 치료를 하여 증상이 사라진다면 BMS가 아니 고, 사라지지 않는다면 다른 질환과 연관된 $\mathrm{BMS}$ 일 가능 성이 있다 BMS라고 진단을 내리는 과정을 다음 모식도 로 요약해 볼 수 있다(Fig. 1). 


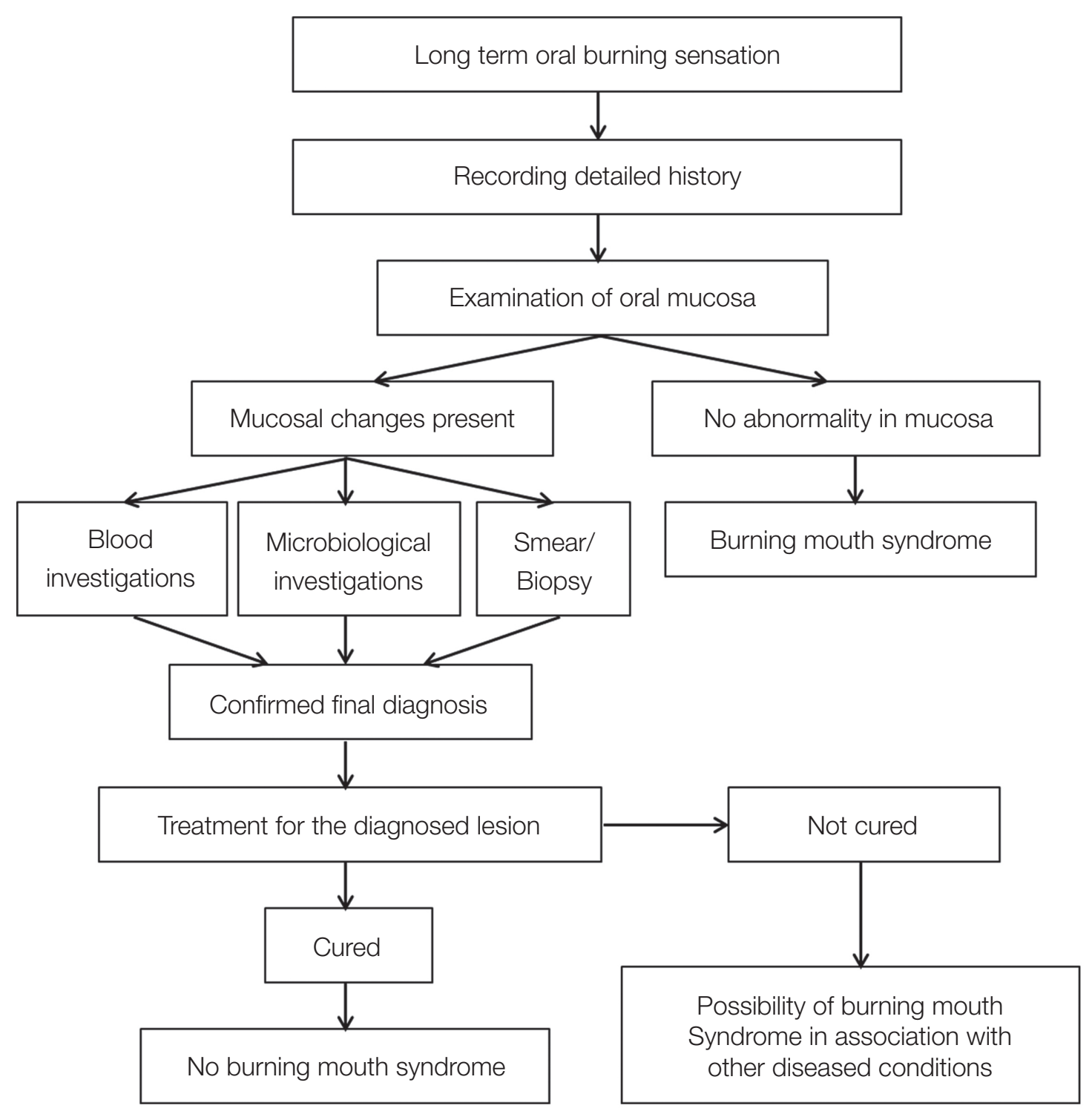

Fig. 1. Flowchart for diagnosis of burning mouth syndrome.

\section{감별진단 (Differential diagnosis)}

임상가들은 임상병리학적 검사를 포함한 적절한 구강 임상검사를 수행하고 환자의 상세한 현증과 의과적, 치 과적, 정신과적인 병력청취를 주의 깊게 하여 BMS와 감 별해야 한다. 이 증상의 다른 원인들이 제외되거나, 감 별된 질환에 대한 치료에 호전되지 않는다면 BMS로 진 단 내릴 수 있다. $\mathrm{BMS}$ 와 감별진단이 필요한 질환들이다 (Table 2). ${ }^{30-32}$

\section{치료 (Treatment)}

잠재적인 병인들의 제거 후에도 환자들이 증상을 호소 한다면 약물요법을 생각해야 한다. BMS는 환자들이 진 단에 대해 이해하고 치료가능성에 대해 현실적으로 받아 들이는 것이 매우 중요하다. 환자들은 이미 많은 의사들 의 상담을 받아왔고, 다양한 치료를 받았지만 그 결과가 만족스럽지 않아 의료진에 대한 불신이 가득한 환자들이 많기 때문에 의사와의 신뢰관계 형성이 중요하다. 그러 
Table 2. Differential diagnosis of burning mouth syndrome (BMS)

\begin{tabular}{|c|c|}
\hline & Differential diagnosis \\
\hline 1 & $\begin{array}{l}\text { Local factors } \\
\text { - Rough restorative material } \\
\text { - Allergic contact stomatitis on dental materials } \\
\text { - Caustic oral rinses, acidic foods } \\
\text { - Parafunctional habits such as cheek/lip/ } \\
\text { mucosa biting }\end{array}$ \\
\hline 2 & Oral Candidiasis \\
\hline 3 & $\begin{array}{l}\text { Mucous skin disease } \\
\text { - Lichen planus, lichenoid reaction, benign mucous } \\
\text { membrane pemphigoid, pemphigus }\end{array}$ \\
\hline 4 & $\begin{array}{l}\text { Viral disease } \\
\text { - Herpes simplex, herpes zoster, postherpetic } \\
\text { neuralgia }\end{array}$ \\
\hline 5 & $\begin{array}{l}\text { Nutrition deficiency } \\
\text { - Iron, zinc, vitamin B complex (specially vitamin } \\
\mathrm{B}_{12} \text { ) }\end{array}$ \\
\hline 6 & Hypothyroidism \\
\hline 7 & Diabetes mellitus \\
\hline 8 & $\begin{array}{l}\text { Gastrointestinal disorder } \\
\text { - Gastroesophageal reflux disease (GERD), } \\
\text { gastritis (Helicobacter pylori infection) }\end{array}$ \\
\hline 9 & $\begin{array}{l}\text { Xerostomia } \\
\text { - Sjögren’s syndrome, radiation therapy, } \\
\text { Drug-induced stress } \\
\text { - Saliva reduction due to aging }\end{array}$ \\
\hline
\end{tabular}

므로 먼저 치료 초기에 환자들에게 충분한 시간을 할애 하고 정기적으로 관찰 약속을 잡음으로써, 환자들 스스 로가 본인이 잘 관리 받고 있다는 느낌을 갖도록 하는 것 이 중요하며, 환자들의 말에 귀를 기울이고 포괄적인 검 사를 시행한 후, 그들에게 암이 아니라고 말해줌으로써 암에 대한 공포를 없애주는 것 또한 중요하다. BMS는 국소적, 전신적, 심리적 요소 또는 말초성/중추성 신경병 리학적 요소 등 다양한 병인에서 기인하기 때문에 주로 한 가지 병인에 초점이 맞추어지는 단일요법은 BMS 환 자들에서 모든 구강 증상을 완전히 제거할 수는 없었다. 따라서 BMS 환자들에게 약물요법과 다른 치료적 접근 을 조합한 복합요법(combination therapy)이 증상개선과 치료기간 단축에 좋은 영향을 줄 것이라고 생각한다.

국소적 치료법으로서 Capsaicin은 구심성 감각신경에 작용하여 Substance $\mathrm{P}$ 를 억제함으로써 구강점막작열감 치료에 탈감작제 또는 진통제로서 사용되었지만 그 향 과 맛 때문에 환자들이 선호하지 않아서, ${ }^{33}$ 현재 임상에 서는 capsaicin은 거의 사용하지 않고, Clonazepam을 처
방하고 있다. Clonazepam은 gamma-amino butyric acid (GABA) 수용체의 작용제로서 국소적으로 사용된 clonazepam은 전신적으로 투여되었을 때의 부작용을 야기하 지 않으면서 구강작열감 증상을 줄일 수 있다. BMS 환자 41명에서 clonazepam 국소적 사용의 효능을 평가했는데 placebo로 치료 받은 대조군보다 통증 점수가 많이 낮았 다. ${ }^{34}$ 이는 clonazepam이 BMS 환자들의 말초신경계장애 와 관련되고, 말초조직의 $\mathrm{GABA}$ 수용체의 존재와 관련 있다는 것을 의미한다. 또한 $70 \%$ 알로에 베라겔 $0.5 \mathrm{~mL}$ 를 혀의 아픈 부위에 하루에 3 번 발라주고 혀 보호대를 장착해주었을 때, 혀의 작열감과 통증 감소에 효과적이 었다. ${ }^{35}$

전신적 치료법으로서 저용량의 amitriptyline은 항우울 효과보다 삼환의 진통효과특성으로 인해 BMS 환자들에 서 유용했고, 항우울 효과를 보이기 위한 용량까지 필요 하지 않았다. ${ }^{36}$ Amitriptyline 25 - $50 \mathrm{mg} /$ day 용량은 감 각 역치를 증가시켰다. 초기 용량은 취침 시 $5-10 \mathrm{mg} /$ $\mathrm{day}$ 에서 시작해서 증상이 사라지거나 부작용이 나타날 때까지 매주 5-10 mg씩 증량했고, 8주 후 복용용량이 $40 \mathrm{mg} / \mathrm{day}$ 에 다다르면 보통 좋은 결과를 제공하였지만, 몇몇 경우에 $150 \mathrm{mg} / \mathrm{day}$ 만큼 고용량이 필요한 경우도 있었다. ${ }^{36}$

다른 항우울제와 다르게 SSRI들은 입안을 마르게 하 는 항콜린효과를 가지고 있지 않기 때문에 우울증을 동 반한 $\mathrm{BMS}$ 증상에 효과적이다. Maina 등 ${ }^{37}$ 은 8 주 동안 amisulpride (50 mg/day), paroxetine (20 mg/day), sultraline $(50 \mathrm{mg} / \mathrm{day})$ 을 사용하고 효과와 내성을 평가했 는데 세 약물 모두 8주 전 보다 구강작열감을 유의하게 감소시켰다고 보고하였다. Amisulpride는 다른 두 약물 보다 순응도가 높고 약효 발현에 걸리는 시간이 짧았다. 세 약물 모두 심각한 부작용은 보이지 않았고, 결과적으 로 amisulpride (50 mg/day), paroxetine $(20 \mathrm{mg} /$ day), sultraline $(50 \mathrm{mg} /$ day)이 BMS 치료에 효과적이었다.

벤조디아제핀은 불안장애를 지닌 BMS 환자들에서 특 히 유용하다. 저용량의 clonazepam은 근본적인 신경병 리학적 메커니즘을 방해하기 때문에 항불안효과 보다 $\mathrm{BMS}$ 통증치료에 좋은 결과를 주었다고 보고되었고, ${ }^{14}$ clonazepam을 취침 시에 $0.25 \mathrm{mg} / \mathrm{day}$ 로 시작해서 증상 이 사라지거나 부작용이 나타날 때까지 4 - 7일마다 0.25 $\mathrm{mg}$ 씩 증량하라는 지침이 제시되었다. ${ }^{38}$

Femiano 등 ${ }^{39}$ 은 60 명의 BMS 환자들을 대상으로 이중 맹검법을 실시하여 ALA $600 \mathrm{mg} / \mathrm{day}$ 용량으로 2개월 동 
안 치료 후에 증상이 유의하게 개선되었다고 보고하였 다. ALA로 치료 받은 환자들의 $70 \%$ 는 개선된 상태가 치 료 1년 후에도 유지되었고, 이러한 결과는 BMS의 신경병 증성 병인에 대한 가설을 지지해준다.

Sun 등 ${ }^{40}$ 은 '비타민 BC캡슐' 또는 '비타민 BC캡슐+조 혈제'를 투여 받은 BMS 환자들 399명 중 44.4\%에서 치 료 후 점막 작열감, 구강건조감, 혀의 감각저하, 미각장애 등의 구강 증상이 완전히 사라졌다고 보고하였다. Cho 등 $^{41}$ 은 BMS 환자 276명의 혈청 아연 농도를 평가했는데 그 중 $26.8 \%$ 에서 평균보다 낮았다. 이 환자들에게 6개월 동안 아연 보충 요법 $(14.1 \mathrm{mg} / \mathrm{day})$ 을 시행한 결과, 정상 대조군에서 통증 수치가 평균 7.7에서 6.7로 감소한 것에 비해 아연 결핍된 $\mathrm{BMS}$ 환자들은 통증 수치가 평균 8.1에 서 4.1로 감소하였다. 이러한 결과는 BMS 환자들에게 적 절한 아연 보충 요법이 구강작열감 또는 통증을 경감시 키는데 효과적이라는 것을 의미한다. Wardrop 등 ${ }^{19}$ 은 구 강 내 불편감의 발병률이 폐경기 이전 여성에서 $(6 \%)$ 보다 폐경기 근처와 폐경기 후 여성에서(43\%) 유의하게 높아 졌다고 발표하였다. 구강 내 임상적인 징후 없이 구강 내 불편감을 지닌 폐경기 여성 환자들의 약 $2 / 3$ 가 호르몬 대 체 요법 후에 구강 증상들이 경감되었다. Forabosco 등 ${ }^{42}$ 도 구강불편감을 지닌 폐경 후 27 명의 환자들을 대상으 로 호르몬 대체 요법의 효능을 평가하였는데, 호르몬 대 체 요법이 구강 증상을 경감시켰고 27 명의 환자 중 15 명 에서 구강 세포학적 특성을 향상시켰다.

$A \operatorname{mos}$ 등 ${ }^{43}$ 은 36명의 BMS 환자들을 대상으로 하루 3 번 $0.5 \mathrm{mg}$ 씩 clonazepam 정제를 바로 삼키지 말고 입안 에서 녹인 다음에 삼키라고 지시한 후, 6 개월 동안 관찰 하였다. 그 결과 환자들 중 약 $80 \%$ 에서 치료기간이 끝난 후 통증이 $50 \%$ 이상 감소하였고, 환자들 중 $33 \%$ 이상에 서 통증이 완전히 사라졌다.

Femiano 등 ${ }^{39}$ 은 192 명의 구강작열감 증후군 환자들을 대상으로 세 군으로 무작위로 나누어 2개월 동안 하루에 2시간씩 심리치료만, 또는 2개월 동안 ALA $600 \mathrm{mg} / \mathrm{day}$ 투여만, 또는 ALA $600 \mathrm{mg} / \mathrm{day}$ 와 심리치료를 병행해서 치료하였는데, 2개월 동안 복합치료를 받은 경우에 BMS 증상이 유의적으로 더욱 개선되었다.

심리 치료는 기존 치료법들과 병행되어 더 나은 치료효 과를 보이고 있다. 인지행동치료는 목표지향적인 체계적 과정을 통해 제 기능을 하지 못하는 감정, 행동 및 인지에 관련된 문제를 해결하기 위한 심리치료적 접근을 말한다. Bergdahl 등 ${ }^{44}$ 은 BMS 환자들을 대상으로 12 - 15주 동안
1 주일에 한 번씩 인지행동치료를 시행하였는데, 치료 후 바로 통증이 감소하였고 6개월 경과관찰 후에도 여전히 효과가 있었다. 이는 인지치료 또한 치료 옵션으로 가능 성 있다는 것을 의미한다.

\section{결론}

$\mathrm{BMS}$ 와 관련된 증상들은 다양하고 부정적인 영향을 주어 삶의 질을 떨어뜨린다. 원인 또한 명확하지 않고 다 양해서 치료와 관리가 쉽지 않아 많은 연구가 이루어져 왔지만 증상 경감을 목표로 하는 한계가 있었다. 환자들 에게 신뢰를 재형성시켜주고 다각적인 면에서 원인요소 를 고려하여 약물적 접근과 심리적 치료의 적절한 조합 으로 환자들의 불편을 해소해주는 것이 필요하다.

\section{ORCID}

Sung-Hyeon Choi https://orcid.org/0000-0002-4324-6567

Bin-Na Lee https://orcid.org/0000-0001-8017-1835

Hae-Soon Limhttps://orcid.org/0000-0002-9782-7164

Won-Mann Oh https://orcid.org/0000-0001-6480-6191

Jae-Hyung Kim https://orcid.org/0000-0001-5646-4371

\section{References}

1. Grushka M. Clinical features of burning mouth syndrome. Oral Surg Oral Med Oral Pathol 1987;63:30-6.

2. Koo J, Gambla C. Cutaneous sensory disorder. Dermatol Clin 1996;14:497-502.

3. Merskey H, Bogduk N. Classification of chronic pain, IASP Task Force on Taxonomy. 2nd ed. Seattle; International Association for the Study of Pain Press; 1994. p.209-14.

4. Muzyka BC, De Rossi SS. A review of burning mouth syndrome. Cutis 1999;64:29-35.

5. Scala A, Checchi L, Montevecchi M, Marini I, Giamberardino MA. Update on burning mouth syndrome: overview and patient management. Crit Rev Oral Biol Med 2003;14:275-91.

6. Locker D, Grushka M. Prevalence of oral and facial pain and discomfort: preliminary results of a mail survey. Community Dent Oral Epidemiol 1987;15:169-72. 
7. Klasser GD, Epstein JB. Oral burning and burning mouth syndrome. J Am Dent Assoc 2012;143:13179.

8. Bergdahl M, Bergdahl J. Burning mouth syndrome: prevalence and associated factors. J Oral Pathol Med 1999;28:350-4.

9. Jääskeläinen SK. Pathophysiology of primary burning mouth syndrome. Clin Neurophysiol 2012;123:71-7.

10. Lamey PJ, Lamb AB. Prospective study of aetiological factors in burning mouth syndrome. Br Med J (Clin Res Ed) 1988;296:1243-6.

11. Chung JW, Kim JH, Kim HD, Kho HS, Kim YK, Chung SC. Chronic orofacial pain among Korean elders: prevalence, and impact using the graded chronic pain scale. Pain 2004;112:164-70.

12. Femiano F, Gombos F, Esposito V, Nunziata M, Scully C. Burning mouth syndrome (BMS): evaluation of thyroid and taste. Med Oral Patol Oral Cir Bucal 2006;11:E22-5.

13. Savage NW, Boras VV, Barker K. Burning mouth syndrome: clinical presentation, diagnosis and treatment. Australas J Dermatol 2006;47:77-81.

14. Nagler RM, Hershkovich O. Sialochemical and gustatory analysis in patients with oral sensory complaints. J Pain 2004;5:56-63.

15. Femiano F, Lanza A, Buonaiuto C, Gombos F, Nunziata M, Cuccurullo L, Cirillo N. Burning mouth syndrome and burning mouth in hypothyroidism: proposal for a diagnostic and therapeutic protocol. Oral Surg Oral Med Oral Pathol Oral Radiol Endod 2008;105:e22-7.

16. Brufau-Redondo C, Martín-Brufau R, CorbalánVelez R, de Concepción-Salesa A. Burning mouth syndrome. Actas DermoSifiliogr 2008;99:431-40.

17. Basker RM, Sturdee DW, Davenport JC. Patients with burning mouth. A clinical investigation of causative factors, including the climacteric and diabetes. Br Dent J 1978;145:9-16.

18. Tourne LP, Fricton JR. Burning mouth syndrome. Critical review and proposed clinical management. Oral Surg Oral Med Oral Pathol 1992;74:158-67.

19. Wardrop RW, Hailes J, Burger H, Reade PC. Oral discomfort at menopause. Oral Surg Oral Med Oral Pathol 1989;67:535-40.
20. Gao J, Chen L, Zhou J, Peng J. A case-control study on etiological factors involved in patients with burning mouth syndrome. J Oral Pathol Med 2009;38:24-8.

21. Woda A, Dao T, Gremeau-Richard C. Steroid dysregulation and stomatodynia (burning mouth syndrome). J Orofac Pain 2009;23:202-10.

22. Zakrzewska JM. Critical commentary 1: steroid dysregulation and stomatodynia (burning mouth syndrome). J Orofac Pain 2009;23:211-3.

23. Lamey PJ, Hammond A, Allam BF, McIntosh WB. Vitamin status of patients with burning mouth syndrome and response to replacement therapy. $\mathrm{Br}$ Dent J 1986;160:81-4.

24. Lin HP, Wang YP, Chen HM, Kuo YS, Lang MJ, Sun A. Significant association of hematinic deficiencies and high blood homocysteine levels with burning mouth syndrome. J Formos Med Assoc 2013;112:319-25.

25. Rhodus NL, Fricton J, Carlson P, Messner R. Oral symptoms associated with fibromyalgia syndrome. J Rheumatol 2003;30:1841-5.

26. Maina G, Albert U, Gandolfo S, Vitalucci A, Bogetto F. Personality disorders in patients with burning mouth syndrome. J Pers Disord 2005;19:84-93.

27. Huang W, Rothe MJ, Grant-Kels JM. The burning mouth syndrome. J Am Acad Dermatol 1996;34:918.

28. Lamey PJ, Freeman R, Eddie SA, Pankhurst C, Rees T. Vulnerability and presenting symptoms in burning mouth syndrome. Oral Surg Oral Med Oral Pathol Oral Radiol Endod 2005;99:48-54.

29. Amenábar JM, Pawlowski J, Hilgert JB, Hugo FN, Bandeira D, Lhüller F, Lopez de Souza MA. Anxiety and salivary cortisol levels in patients with burning mouth syndrome: case-control study. Oral Surg Oral Med Oral Pathol Oral Radiol Endod 2008;105:460-5.

30. Coculescu EC, Radu A, Coculescu BI. Burning mouth syndrome: a review on diagnosis and treatment. J Med Life 2014;7:512-5.

31. Aravindhan R, Vidyalakshmi S, Kumar MS, Satheesh C, Balasubramanium AM, Prasad VS. Burning mouth syndrome: A review on its diagnostic and therapeutic approach. J Pharm Bioallied Sci 
2014;6:S21-5.

32. Grushka M, Epstein JB, Gorsky M. Burning mouth syndrome: differential diagnosis. Dermatol Ther 2002;15:287-91.

33. Epstein JB, Marcoe JH. Topical application of capsaicin for treatment of oral neuropathic pain and trigeminal neuralgia. Oral Surg Oral Med Oral Pathol 1994;77:135-40.

34. Gremeau-Richard C, Woda A, Navez ML, Attal N, Bouhassira D, Gagnieu MC, Laluque JF, Picard P, Pionchon P, Tubert S. Topical clonazepam in stomatodynia: a randomised placebo-controlled study. Pain 2004;108:51-7.

35. López-Jornet P, Camacho-Alonso F, MolinoPagan D. Prospective, randomized, double-blind, clinical evaluation of Aloe vera Barbadensis, applied in combination with a tongue protector to treat burning mouth syndrome. J Oral Pathol Med 2013;42:295-301.

36. Mancuso G, Berdondini RM. Simultaneous occurrence of dysaesthetic peno/scroto-dynia and stomatodynia. Int J STD AIDS 2005;16:830-1.

37. Maina G, Vitalucci A, Gandolfo S, Bogetto F. Comparative efficacy of SSRIs and amisulpride in burning mouth syndrome: a single-blind study. J Clin Psychiatry 2002;63:38-43.

38. Culhane NS, Hodle AD. Burning mouth syndrome after taking clonazepam. Ann Pharmacother
2001;35:874-6.

39. Femiano F, Gombos F, Scully C. Burning mouth syndrome: the efficacy of lipoic acid on subgroups. J Eur Acad Dermatol Venereol 2004;18:676-8.

40. Sun A, Lin HP, Wang YP, Chen HM, Cheng SJ, Chiang CP. Significant reduction of serum homocysteine level and oral symptoms after different vitamin-supplement treatments in patients with burning mouth syndrome. J Oral Pathol Med 2013;42:474-9.

41. Cho GS, Han MW, Lee B, Roh JL, Choi SH, Cho KJ, Nam SY, Kim SY. Zinc deficiency may be a cause of burning mouth syndrome as zinc replacement therapy has therapeutic effects. J Oral Pathol Med 2010;39:722-7.

42. Forabosco A, Criscuolo M, Coukos G, Uccelli E, Weinstein R, Spinato S, Botticelli A, Volpe A. Efficacy of hormone replacement therapy in postmenopausal women with oral discomfort. Oral Surg Oral Med Oral Pathol 1992;73:570-4.

43. Amos K, Yeoh SC, Farah CS. Combined topical and systemic clonazepam therapy for the management of burning mouth syndrome: a retrospective pilot study. J Orofac Pain 2011;25:125-30.

44. Bergdahl J, Anneroth G, Perris H. Cognitive therapy in the treatment of patients with resistant burning mouth syndrome: a controlled study. J Oral Pathol Med 1995;24:213-5. 


\section{구강작열감 증후군에 대한 논문 고찰}

\section{최성현 ${ }^{1}$, 이빈나 ${ }^{1}$, 임회순 ${ }^{2}$, 오원만 $^{1}$, 김재형 ${ }^{3 *}$}

${ }^{1}$ 전남대학교 치과대학 보존학교실

${ }^{2}$ 전남대학교 치과대학 치의학교육학교실

${ }^{3}$ 전남대학교 치과대학 구강내과학교실

구강작열감 증후군은 점막 이상 등의 임상소견이 없는 상태에서 혀 및 구강점막의 작열감과 구강건조감, 미각이상 등의 불편감을 호소하는 증상으로, 남녀 모두에서 나타날 수 있으나 중년의 폐경기 여성에서 빈발한다. 임상에서 진단이 쉽지 않고 명확한 원인을 밝히기 어려워 증상 경감을 치료목표로 해왔다. 병인은 국소적, 전신적 및 심리적 요인으로 나뉘고 치료는 $\alpha$-lipoic acid, clonazepam, 영양보충 등의 약물요법과 인지행동치료 등이 있으며 최근에는 단일 치료법보다는 복 합요법의 높은 효과에 대해 관심이 모아지고 있다. 다각적인 면에서 원인요소를 고려하여 약물적 접근과 인지행동요법 을 포함한 심리치료 병행으로 환자들의 증상을 경감해주는 것이 필요하다.

(구강회복응용과학지 2019;35(3): 123-31)

주요어: 구강작열감 증후군; 임상적 특징; 병인; 진단; 치료 